\title{
Peranan Humor terhadap Stres pada Remaja, dengan Kecerdasan Emosi sebagai Mediator
}

\author{
Erik Wijaya \\ Fakultas Psikologi Universitas Tarumanagara
}

\begin{abstract}
This study wanted to test the role of humor towards stress, with emotional intelligence as a mediator variable in adolescent. Research on humor in Indonesia has been done by involving the subject of a student who is writing a thesis, a student in the first year, a graduate student, as well as in middle adulthood. Based on this, researchers want to do further research to emphasize the role of humor with emotional intelligence as a mediator in adolescent. Research is done early in adolescent because the stressful sources of school and the peer group as part of the developmental tasks. Based on the results of this study found emotional intelligence has a role as a variable mediator of superiority humor and cognitive humor to stress.
\end{abstract}

Keywords: Humor, emotional intelligence, stress, adolescent.

\section{Pendahuluan}

Masa remaja ditandai oleh perubahan yang besar diantaranya kebutuhan untuk beradaptasi dengan perubahan fisik dan psikologis, termasuk dalam menyelesaikan tugas perkembangannya

Erik Wijaya adalah Dosen Fakultas
Psikologi Universitas
$\begin{aligned} & \text { Korespondensi artikel dialamatkan ke: } \\ & \text { erikw@fpsi.untar.ac.id }\end{aligned}$

yakni pencarian identitas diri. Masa remaja merupakan masa ketika remaja dihadapkan pada berbagai hal dan tantangan diantaranya adalah tuntutan dalam menyelesaikan tugas akademik, tuntutan dalam hubungan pertemanan dan dalam relasi dengan orangtua (Papalia, Feldman, \& Martorell, 2012). 


\section{Kajian Pustaka}

\section{Stres}

Tuntutan-tuntutan bisa dianggap sebuah stressor bagi remaja yang dapat memicu munculnya stres ketika remaja tidak berhasil untuk memenuhi tuntutan yang diberikan kepadanya (Papalia et al., 2012). Lazarus (dikutip dalam Lahey, 2007) mengatakan bahwa stres dapat diartikan sebagai kesenjangan antara tuntutan lingkungan dan kemampuan individu untuk menangani tuntutan lingkungan atau situasi tersebut.

Lazarus dan Folkman (dalam

Davison, Neale, \& Kring, 2006), mengidentifikasi coping dalam dua dimensi, yang pertama coping yang berfokus pada masalah (problem focused coping) mencakup bertindak secara langsung untuk mengatasi masalah. Kedua adalah coping yang berfokus pada emosi (emotion - focused coping) merujuk pada berbagai upaya untuk mengurangi berbagai reaksi emosional negatif terhadap stres. Diketahui kebanyakan individu cederung menggunakan emotion focused coping terlebih dahulu ketika berhadapan dengan stres. Salah satunya adalah dengan berhumor.

\section{Humor}

Menurut Driver (dalam Hartanti, 2002), humor merupakan sifat dari sesuatu atau suatu situasi yang kompleks yang menimbulkan keinginan untuk tertawa. Secara sederhana humor didefinisikan sebagai sesuatu yang lucu. Eysenck (dikutip dalam Utomo, 2009) menyebutkan humor adalah sesuatu yang dapat membuat tertawa. Hasanat dan Subandi (1998) mengatakan humor dinilai dapat menimbulkan emosi positif, sebab humor menjadikan seseorang dapat tersenyum ataupun tertawa dan memunculkan emosi positif. Humor dapat membuat seseorang 
menjadi lebih rileks, tidak tegang, Muawanah, Suroso, dan Pratikno (2012) sehingga pikiran pun dapat lebih menyatakan pada masa remaja, individu berkonsentrasi untuk menyelesaikan belum mampu mengontrol emosinya masalah.

dengan baik dan belum mampu untuk Berdasarkan penelitian yang mengeskpresikan emosinya dengan cara dilakukan oleh Berk dan Tan, humor yang dapat diterima masyarakat. dapat mereduksi hormon yang Kemampuan mengkontrol emosi yang menyebabkan stres seperti cortisol, rendah menyebabkan gangguan perilaku epinephrine, dan dopac (dikutip dalam pada remaja. Rini, Hardjajani, dan Borchard, 2015). Selanjutnya Lefcourt Nugroho (2012) menambahkan bahwa memberikan pernyataan bahwa rasa remaja yang memiliki kecerdasan emosi humor sudah sejak lama menjadi tinggi akan dapat mengendalikan dan kualitas pribadi yang dapat melunakkan mengelola emosinya sendiri. Oleh stres dalam kehidupan seseorang karena itu, kecerdasan emosi merupakan (dikutip dalam Cann, Stilwell, \& Taku, salah satu aspek penting yang harus 2010). dimiliki oleh remaja.

Berdasarkan hal tersebut, humor merupakan variabel psikologis yang Emotional Intelligence (kecerdasan dapat mereduksi stres. Ditinjau dari emosi)

Goleman (2000) mengemukakan perkembangan remaja, faktor kecerdasan emosi adalah kemampuan kecerdasan emosi juga memiliki kemampuan untuk memotivasi diri peranan mereduksi stres dan sendiri dan bertahan menghadapi berhubungan juga dengan humor. frustasi; mengendalikan dorongan hati 
dan tidak melebih-lebihkan kesenangan; memiliki kecerdasan emosi memiliki mengatur suasana hati dan menjaga agar kemampuan bergaul yang baik, harapan beban stres tidak melumpuhkan yang tinggi, sehingga tidak akan kemampuan berpikir; dan berempati. terjebak dalam kecemasan, bersikap Sedangkan, Salovey dan Mayer (1997), pasrah, atau depresi/frustasi dalam menyatakan bahwa kecerdasan emosi menghadapi masalah. Individu dengan adalah kemampuan untuk memahami kecerdasan emosi mampu secara akurat, menilai, dan memanfaatkan kecemasan antisipasi, mengekspresikan emosi; kemampuan misalnya ketika akan menghadapi ujian, untuk mengakses dan menghasilkan mereka mampu memotivasi diri untuk perasaan ketika mereka memfasilitasi mempersiapkan diri dengan baik pengalaman; kemampuan untuk sehingga dapat melakukan dengan memahami emosi dan memiliki sempurna.

pengetahuan emosi; kemampuan untuk Menurut Lantieri (dalam Goleman, secara reflektif mengatur emosi dengan 2000) keterampilan atau kecerdasan cara yang mendukung pertumbuhan emosi merupakan aspek penting dalam emosi dan intelektual.

Menurut Goleman (2000) terdapat 5 pada remaja di sekolah. Sedangkan, aspek dalam kecerdasan emosi, yaitu Mukarromah (2008) juga menyatakan mengenali emosi diri, mengelola emosi, bahwa individu dengan kecerdasan memotivasi diri sendiri, mengenali emosi yang tinggi dapat melakukan emosi orang lain, dan membina problem solving dan decision making hubungan. Secara umum, orang yang yang lebih baik terhadap berbagai 
masalah yang menekan kehidupannya.

Berdasarkan hal tersebut maka Desain dan Subjek Penelitian

keterkaitan antara kecerdasan emosi

yang dimiliki oleh remaja akan

membuat stres dalam hidupnya sehari-

hari menjadi lebih berkurang karena di

dalam komponen kecerdasan emosi

terdapat kemampuan-kemampuan

menyelesaikan stres secara emosi

seperti memotivasi diri sendiri. Selain

itu, penggunaan humor untuk mereduksi

stres sekaligus terkait dengan

kecerdasan emosi juga faktor penting

untuk dilihat. Hal ini dikarenakan

berdasarkan hasil penelitian terdahulu

dari Wijaya dan Basaria (2017) yang

menemukan adanya hubungan

signifikan antara humor dengan

kecerdasan emosi. Dengan demikian

penelitian ini dilakukan untuk melihat

peranan humor terhadap stres dengan

kecerdasan emosi sebagai mediator pada

remaja.

\section{Metode}

Pendekatan yang digunakan dalam penelitian ini adalah pendekatan kuantitatif. Selanjutnya penelitian ini pada dasarnya bertujuan untuk melihat adanya peranan humor terhadap stres dengan kecerdasan emosi sebagai mediator pada remaja. Subjek penelitian yang bertindak sebagai partisipan dipilih dengan metode convenience sampling yaitu subjek yang dipilih berdasarkan kemudahan (pada lingkungan yang dapat dijangkau oleh peneliti). Subjek sebagai partisipan adalah individu berusia 11-20 tahun, jenis kelamin, tingkat pendidikan, agama dan status sosial ekonomi tidak dibatasi. Jumlah responden direncanakan sebanyak 400 orang yang akan diambil dari sekolah serta universitas di Jakarta. 


\section{Identifikasi Variabel}

Sesuai dengan judul "peranan humor terhadap stres dengan kecerdasan emosi sebagai mediator pada remaja." maka variabel yang ada dalam penelitian ini adalah, (a) variabel bebas yaitu humor, (b) variabel terikat yaitu stres, dan (c) variabel mediator yaitu kecerdasan emosi.

\section{Instrumen}

Instrumen atau alat ukur yang digunakan dalam penelitian ini adalah kuesioner. Ada tiga kuesioner yang digunakan dalam penelitian ini yaitu (a) kuesioner humor, (b) kuesioner kecerdasan emosi dan (c) kuesioner stres. Ketiga alat ukur dari variabel penelitian ini diukur dengan menggunakan alat ukur yang sudah dipinjam dari Bagian Riset dan Pengukuran Psikologi Universitas Tarumanagara.

\section{Prosedur Penelitian}

Persiapan penelitian dilakukan sejak menyusun proposal penelitian, dimulai dengan mencari literatur yang sesuai dengan topik penelitian. Literatur yang dicari tersebut adalah untuk menjadikan dasar pemikiran untuk diadakannya penelitian. Setelah sumber literatur diperoleh, maka peneliti mempersiapkan alat ukur serta target subyek untuk melakukan penyebaran data penelitian.

\section{Pelaksanaan Penelitian}

Pengumpulan data dilakukan dengan menyebarkan kuesioner pada salah satu universitas di Jakarta. Setelah data terkumpul, kemudian data tersebut diolah dengan menggunakan SPSS. Teknik analisis data yang digunakan dalam penelitian ini adalah menggunakan regresi. Isian kuesioner dari partisipan penelitian juga telah selesai dimasukkan di dalam master 
table SPSS. Tahapan selanjutnya adalah melakukan pengolahan data dengan bantuan program LISREL 8.8 untuk pengujian hipotesis karena pengujian terdapat variabel mediator.

\section{Pengukuran Variabel Penelitian}

Pengukuran validitas dari penelitian ini menggunakan pengujian confirmatory factor analysis (CFA) dengan bantuan program LISREL 8.8. Dengan menggunakan CFA maka akan dapat diketahui secara keseluruhan apakah butir-butir dari alat ukur merupakan butir yang memiliki kemampuan untuk mengukur aspek yang ingin diukur atau tidak. Hal tersebut dapat tercermin dari nilai loading factor yang baik (>0.2).

Alat ukur pertama pada penelitian ini adalah sense of humor yang merupakan alat ukur pengembangan dari alat ukur Bagian Riset dan Pengukuran Psikologi Universitas Tarumanagara. Dimensi pertama yaitu humor cognitive memiliki jumlah 13 butir berupa gambar-gambar, seluruhnya terdiri dari butir positif. Humor cognitive merupakan jenis humor yang mengindikasikan individu menyukai humor yang menggunakan pola penalaran (berpikir). Semakin tinggi skor pada jenis humor ini, maka individu dominan pada tipe humor ini, demikian sebaliknya.

Dimensi kedua yaitu humor netral memiliki jumlah 11 butir berupa gambar-gambar, seluruhnya adalah butir positif. Humor netral merupakan jenis humor yang mengindikasikan individu menyukai humor yang melihat respon gambar yang terkesan cute. Semakin tinggi skor pada jenis humor ini, maka individu dominan pada tipe humor ini, demikian sebaliknya.

Dimensi ketiga humor superiority memiliki jumlah 10 butir berupa gambar-gambar, seluruhnya merupakan 
butir positif. Humor superiority marah, saya tahu penyebab kemarahan merupakan jenis humor yang saya.

mengindikasikan individu menyukai Dimensi kedua dari kecerdasan humor yang senang/tertawa ketika emosi adalah mengelola emosi atau melihat orang lain mengalami managing emotions, yaitu kemampuan kesukaran, penderitaan, wajah yang untuk mengatur perasaan agar perasaan buruk rupa, dan sebagainya. Semakin tersebut dapat diungkapkan secara tepat. tinggi skor pada jenis humor ini, maka Contoh butir yang termasuk dalam individu dominan pada tipe humor ini, dimensi ini adalah sebagai berikut, demikian sebaliknya.

pernyataan positif: saat saya sedih, saya

Alat ukur kedua yaitu kecerdasan tetap melakukan tanggung jawab saya. emosi dikembangkan oleh Badan Riset dan Pengukuran Universitas Tarumanagara berdasarkan teori dari Goleman (2000) yang terdiri dari 5 dimensi. Dimensi pertama dari kecerdasan emosi adalah mengenali emosi diri atau self-awareness, yaitu kemampuan untuk mengenali perasaan atau emosi ketika perasaan tersebut terjadi. Contoh butir yang termasuk dalam dimensi ini adalah sebagai berikut, pernyataan positif: ketika saya Contoh pernyataan negatif: ketika saya marah, saya membanting barang yang ada disekitar saya.

Dimensi ketiga dari kecerdasan emosi adalah memotivasi diri sendiri atau motivating oneself, yaitu kemampuan untuk memotivasi diri, menguasai diri, dan ketahanan dalam menghadapi kegagalan atau perasaan frustasi. Contoh butir yang termasuk dalam dimensi ini adalah sebagai berikut, pernyataan positif: ketika saya 
gagal dalam ujian, saya tetap berpikir positif. Contoh butir negatif: Saya merasa putus asa ketika kesulitan menghampiri saya.

Dimensi keempat dari kecerdasan emosi adalah mengenali emosi orang lain atau emphaty skill, yaitu kemampuan untuk berempati, peduli terhadap orang lain, dan mampu menangkap sinyal-sinyal sosial yang tersembunyi. Contoh butir yang termasuk dalam dimensi ini adalah sebagai berikut, pernyataan positif: Saya dapat dengan mudah merasakan apa yang orang lain rasakan. Contoh pernyataan negatif: Saya mengetahui perasaan teman saya setelah teman saya mengutarakannya.

Dimensi kelima dari kecerdasan emosi adalah membina hubungan atau handling relationship, yaitu kemampuan mengelola emosi orang lain dan keterampilan ini merupakan keterampilan yang menunjang popularitas, kepemimpinan, dan keberhasilan antar pribadi. Contoh butir yang termasuk dalam dimensi ini adalah sebagai berikut, pernyataan positif: saya sering menjadi pemimpin dalam suatu kelompok. Contoh pernyataan negatif: saya sulit bergaul dalam lingkungan saya.

Pengukuran variabel ketiga yaitu variabel stres. Dalam penelitian ini teori stres yang digunakan merujuk dari Christian (2005) yang telah diadaptasi oleh Bagian Riset dan Pengukuran Fakultas Psikologi Universitas Tarumanagara pada tahun 2014. Dalam pengukuran yang menggunakan alat ukur stres, terdiri dari tiga gejala yaitu gejala fisik, gejala mental, dan gejala perilaku. Definisi operasional yang pertama dari stres yaitu gejala fisik. Stres dalam wujud gejala fisik digambarkan dalam bentuk 
menegangnya otot-otot sekitar tulang meliputi sakit kepala, wajah berkerut, gigi bergemerutuk, nyeri rahang, gagap, bibir dan tangan bergetar, otot tegang dan nyeri, nyeri leher, nyeri punggung, bahasa tubuh agresif. Semakin tinggi skor gejala fisik yang diperoleh subyek, maka semakin tinggi pula stres secara fisik yang dialami subyek. Begitu pula hal ini berlaku sebaliknya.

Definisi operasional yang kedua dari stres adalah gejala mental. Stres dalam wujud gejala mental digambarkan dalam bentuk gelisah, khawatir, rasa bersalah dan tegang, peningkatan rasa marah dan frustrasi, perasaan berubah-ubah, depresi, nafsu makan meningkat atau malah menurun, pikiran terburu-buru, mimpi buruk, kesulitan belajar sesuatu yang baru, kesulitan konsentrasi, mudah lupa, disorganisasi atau kebingungan, kesulitan membuat keputusan, lebih sering menangis, pikiran bunuh diri, takut dekat dengan orang lain, dan kesepian. Semakin tinggi skor gejala mental yang diperoleh subyek, maka semakin tinggi pula stres secara mental yang dialami subyek. Begitu pula hal ini berlaku sebaliknya.

Definisi operasional yang ketiga dari stres yaitu gejala perilaku. Stres dalam wujud gejala perilaku digambarkan dalam bentuk tidak memperhatikan cara berpakaian dan penampilan, keterlambatan yang meningkat, perilaku yang tidak biasa, jalan bolak-balik, mudah beraksi pada hal-hal kecil, perfeksionis, meningkatkan kecelakaan kecil, berbohong, berbicara terlalu cepat dan tidak jelas, sikap defensif dan penuh curiga, komunikasi yang tegang dengan orang lain, menarik diri secara sosial, mengalami kesulitan tidur, sering menggunakan obat-obat, tubuh makin gemuk atau makin kurus, makin banyak merokok, meningkatnya penggunaan 
alkohol. Semakin tinggi skor gejala berdasarkan loading factor yang perilaku yang diperoleh subyek, maka terkandung dalam berbagai butir alat semakin tinggi pula stres perilaku yang ukur pada berbagai dimensi variabel tampak telah dialami subyek. Begitu penelitian telah menunjukkan angka > pula hal ini berlaku sebaliknya.

0.2. Pada pengukuran ini, peneliti

Berdasarkan hasil pengukuran memilih masing-masing empat butir dengan teknik CFA yang dilakukan dari dimensi yang memiliki loading pada ketiga variabel penelitian, factor tertinggi. Dari hasil pengujian diketahui bahwa alat ukur yang CFA dengan LISREL 8.8 diperoleh digunakan sudah mencerminkan aspek hasil yang dapat dilihat pada gambar 2. yang diukur. Hal ini dikarenakan

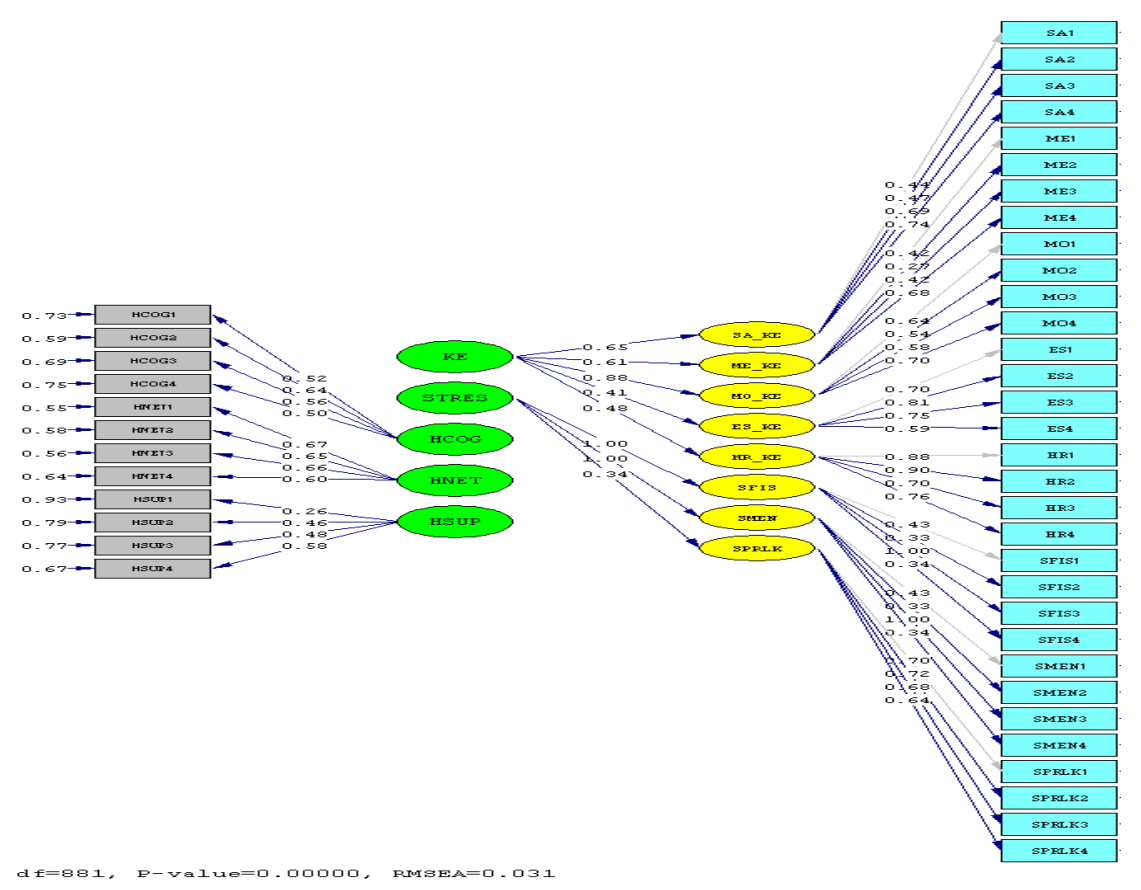

Gambar 1. Tampilan Output Standardized 
Berdasarkan hasil pengujian CFA pengujian ini juga diketahui bahwa tersebut dapat dilihat bahwa alat ukur berbagai nilai yang menjadi indikator yang digunakan telah sesuai untuk model fit (Goodness of Fit) sudah mengukur aspek yang akan diukur. terpenuhi. Secara ringkas indikator Pengujian selanjutnya dapat ditinjau model fit yang sudah terpenuhi dapat dari kecocokan model CFA secara dilihat pada tabel 1 .

keseluruhan. Berdasarkan hasil

\begin{tabular}{|c|c|c|}
\hline Ukuran GOF & Target Kecocokan & Keterangan \\
\hline $\begin{array}{ll}\text { Normal } & \text { Theory }\end{array}$ & $p$ value $>0.05$ & No Fit \\
\hline Weighted Least Squares & & \\
\hline $\begin{array}{l}\text { Chi-Square }=1224.93 \\
(\mathrm{P}=0.00)\end{array}$ & & \\
\hline RMSEA $=0.031$ & $0.05 \leq$ RMSEA $<0.08$ & Good Fit \\
\hline $\mathrm{NFI}=0.89$ & $\geq 0.90$ & No Fit \\
\hline $\mathrm{NNFI}=0.96$ & $\geq 0.90$ & Good Fit \\
\hline $\mathrm{CFI}=0.97$ & $\geq 0.90$ & Good Fit \\
\hline IFI $=0.97$ & $\geq 0.90$ & Good Fit \\
\hline $\mathrm{RFI}=0.88$ & $\geq 0.90$ & No Fit \\
\hline $\mathrm{RMR}=0.067$ & $\leq 0.10$ & Good Fit \\
\hline $\begin{array}{l}\text { Standardized } \mathrm{RMR}= \\
0.063\end{array}$ & $\leq 0.10$ & Good Fit \\
\hline $\mathrm{GFI}=0.88$ & $\geq 0.90$ & No Fit \\
\hline AGFI $=0.86$ & $0.80 \leq \mathrm{AGFI}<0.90$ & Medium Fit \\
\hline
\end{tabular}

Berdasarkan kriteria Goodness of Fit dikatakan bahwa pengukuran yang (GOF) Model di atas maka model dilakukan telah sesuai untuk mengukur penelitian telah memiliki model yang variabel yang ingin diukur dikarenakan baik. Hal ini dikarenakan dari 11 kriteria nilai kecocokan model sudah baik yang ada, terdapat 8 dari kriteria disertai juga dengan loading factor tersebut sudah terpenuhi. Dengan yang tinggi. demikian melalui pengujian CFA dapat 


\section{Hasil dan Pembahasan}

\section{Gambaran Subyek Penelitian}

Pada bagian ini diberikan gambaran dari subyek penelitian. Gambaran subyek penelitian ini pertama adalah berdasarkan jenis kelamin. Berdasarkan data yang diperoleh mengenai jenis kelamin subyek penelitian, jumlah laki-laki sejumlah 189 orang subyek $(47.3 \%)$ dan subyek perempuan sebanyak 211 orang subyek (52.8\%). Gambaran subyek penelitian berikutnya adalah berdasarkan pendidikan terakhir. Berdasarkan data yang diperoleh mengenai pendidikan akhir subyek penelitian, jumlah terbanyak adalah memiliki pendidikan terakhir SMP sejumlah 28 orang subyek $(7 \%)$ dan subyek berpendidikan SMA sebanyak 372 orang subyek (93\%).

\section{Gambaran Data dan Penggolongan Variabel Penelitian}

Pada bagian ini akan dibahas mengenai gambaran variabel penelitian. Gambaran data untuk variabel stres menggunakan skala 1-5 memiliki mean hipotetik alat ukur yaitu 3, sedangkan mean empirik adalah 2.4989. Skor mean empirik lebih kecil dibandingkan dengan skor mean hipotetik dengan demikian maka stres subjek dapat dikatakan rendah. Gambaran selanjutnya yaitu variabel kecerdasan emosi menggunakan skala 1-5 memiliki mean hipotetik alat ukur yaitu 3, sedangkan mean empirik adalah 3.6331 . Skor mean empirik lebih besar dibandingkan dengan skor mean hipotetik dengan demikian maka kecerdasan emosi subjek dapat dikatakan tinggi. Gambaran selanjutnya yaitu variabel humor menggunakan skala 1-5 memiliki mean 
hipotetik alat ukur yaitu 3, sedangkan mean empirik pada humor netral adalah 3.6665, humor cognitive adalah 3.0765 dan humor superiority adalah 3.1827. Skor mean empirik lebih besar dibandingkan dengan skor mean hipotetik dengan demikian maka humor

Tabel 2. Gambaran Variabel Penelitian

\begin{tabular}{llllll}
\hline & $\mathrm{N}$ & Minimum & Maximum & Mean & SD \\
\hline Humor_superiority & 400 & 1.57 & 5.00 & 3.1827 & 0.65218 \\
Humor_netral & 400 & 1.27 & 5.00 & 3.6665 & 0.62375 \\
Humor_cognitive & 400 & 1.42 & 4.85 & 3.0765 & 0.61393 \\
Kecerdasan emosi & 400 & 2.49 & 4.92 & 3.6331 & 0.39220 \\
Stres & 400 & 1.17 & 4.01 & 2.4989 & 0.51280 \\
\hline
\end{tabular}

\section{Uji Normalitas Variabel Penelitian}

Berdasarkan data yang diperoleh, uji normalitas data dilakukan terhadap variabel penelitian. Uji normalitas data menggunakan One Sample KolmogorovSmirnov. Pada variabel stres, nilai $\mathrm{Z}=$ 0.506 dan $p=0.960>0.05$ sehingga penyebaran data untuk stres terdistribusi normal. Pada variabel kecerdasan emosi, nilai $Z=0.500$ dan $p=0.964>$ 0.05 sehingga penyebaran data untuk variabel Kecerdasan Emosi terdistribusi subjek dapat dikatakan tinggi dan yang paling tinggi/dominan pada rata-rata subyek penelitian adalah humor netral. Sebagai rangkuman mengenai gambaran umum dari masing-masing variabel penelitian dapat dilihat pada Tabel 2. 
terdistribusi normal. Berdasarkan uji dapat dilakukan. Hasil uji normalitas normalitas pada berbagai variabel dapat dilihat secara detail pada Tabel 3. penelitian, maka pengujian hipotesis penelitian untuk menguji mediasi dari variabel menggunakan regresi linear

Tabel 3. Hasil Uji Normalitas Variabel Penelitian

\begin{tabular}{lcc}
\hline \multicolumn{1}{c}{ Variabel } & Kolmogorov-Smirnov $Z$ & $\mathrm{p}$ \\
\hline Stres & 0.506 & 0.960 \\
Kecerdasan Emosi & 0.500 & 0.964 \\
Humor Netral & 1.327 & 0.059 \\
Humor Cognitive & 0.721 & 0.677 \\
Humor Superiority & 0.994 & 0.277 \\
\hline
\end{tabular}

Pengujian Hipotesis

Peran Humor terhadap Stres dengan Mediator Kecerdasan Emosi

Pengujian hipotesis penelitian menggunakan Lisrel 8.8. Program ini menghasilkan 3 path yaitu estimates, standardized dan $t$ values. Bagian estimates merupakan nilai untuk persamaan regresi, standardized merupakan nilai koefisien beta dan $t$ values merupakan nilai uji $\mathrm{t}$ hitung. Kemudian berdasarkan tampilan $t$ values dapat dilihat besar peranan dari masing-masing variabel independen terhadap variabel dependen. Berdasarkan hasil pengolahan data, hasil yang diperoleh dapat dilihat pada gambar 2. 


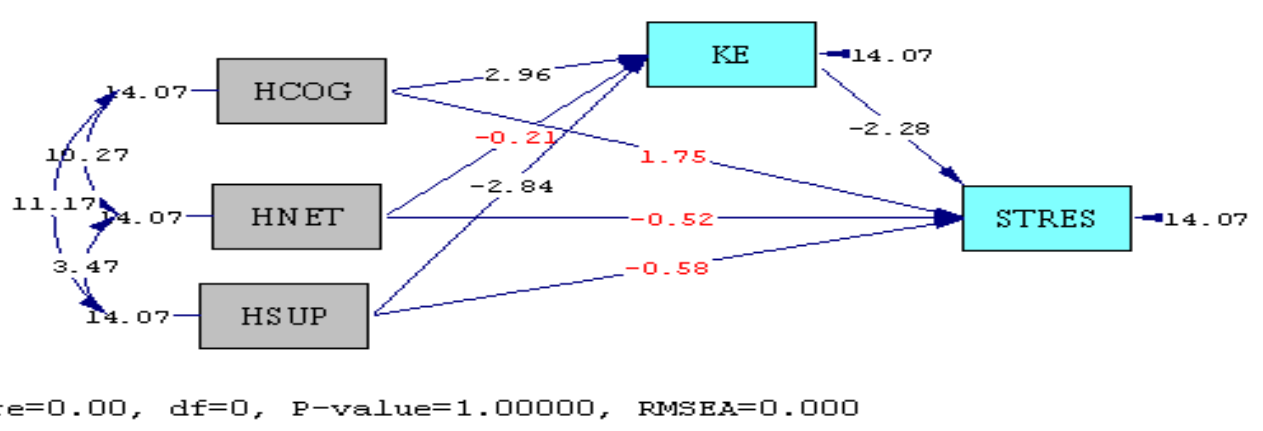

Gambar 2. Tampilan T Values Model Penelitian

Berdasarkan gambar di atas, pengujian model dari penelitian menunjukkan bahwa nilai kecocokan model sudah fit (model memiliki kecocokan yang sangat baik) karena nilai Chi-Square $=0.00, \mathrm{p}$ value $=1.00$ dan RMSEA $=0.00$. Berdasarkan hasil uji pada tampilan nilai t, maka diperoleh hasil variabel kecerdasan emosi merupakan variabel mediator untuk peranan humor cognitive terhadap stres dan juga untuk peranan humor superiority terhadap stres. Hal ini dapat dilihat dari variabel humor cognitive memberikan peran signifikan kepada variabel kecerdasan emosi dengan nilai $t=2.96>1.96$, jadi dengan demikian memiliki peran positif dan signifikan. Kemudian peran kecerdasan emosi terhadap stres ditunjukkan dengan nilai $\mathrm{t}=-2.28>1.96$, jadi dengan demikian terdapat peran yang negatif dan signifikan. Kemudian peranan langsung dari humor cognitive terhadap stres ditunjukkan dengan nilai t $=1.75<1.96$, jadi tidak terdapat peran signifikan. Dengan demikian maka hasil tersebut menunjukkan bahwa kecerdasan emosi merupakan mediator dari peranan humor cognitive terhadap stres.

Hasil berikutnya adalah humor superiority memberikan peran 
signifikan kepada variabel kecerdasan emosi dengan nilai $\mathrm{t}=-2.84>1.96$, jadi dengan demikian memiliki peran negatif dan signifikan. Kemudian peran kecerdasan emosi terhadap stres ditunjukkan dengan nilai $\mathrm{t}=-2.28>$ 1.96, jadi dengan demikian terdapat peran yang negatif dan signifikan. Kemudian peranan langsung dari humor cognitive terhadap stres ditunjukkan dengan nilai $\mathrm{t}=-0.58<1.96$, jadi tidak terdapat peran signifikan. Dengan demikian maka hasil tersebut menunjukkan bahwa kecerdasan emosi merupakan mediator dari peranan humor superiority terhadap stres.

Hasil berikutnya adalah humor netral tidak berperan signifikan kepada variabel kecerdasan emosi dengan nilai $t$ $=-0.21>1.96$, jadi dengan demikian tidak terdapat peran signifikan. Kemudian peran kecerdasan emosi terhadap stres ditunjukkan dengan nilai t
$=-2.28>1.96$, jadi dengan demikian terdapat peran yang negatif dan signifikan. Kemudian peranan langsung dari humor netral terhadap stres ditunjukkan dengan nilai $\mathrm{t}=-0.52<$ 1.96, jadi tidak terdapat peran signifikan. Dengan demikian maka hasil tersebut menunjukkan bahwa kecerdasan emosi bukan merupakan mediator dari peranan humor netral terhadap stres.

\section{Kesimpulan dan Saran}

\section{Kesimpulan}

Berdasarkan hasil pengolahan data diperoleh hasil bahwa ternyata ditemukan adanya peranan negatif dan signifikan humor superiority terhadap kecerdasan emosi. Dengan demikian hal ini menunjukkan bahwa apabila kecerdasan emosi tinggi maka humor superiority menjadi rendah, begitu juga sebaliknya apabila kecerdasan emosi 
rendah maka humor superiority menjadi tinggi.

Selanjutnya berdasarkan hasil pengolahan data diperoleh hasil bahwa ternyata ditemukan adanya peranan negatif dan signifikan kecerdasan emosi terhadap stres. Dengan demikian hal ini menunjukkan bahwa apabila kecerdasan emosi tinggi maka stres menjadi rendah, begitu juga sebaliknya apabila kecerdasan emosi rendah maka stres menjadi tinggi. Sedangkan untuk peranan humor superiority terhadap stres tidak signifikan. Dengan demikian maka terbentuk mediasi pada peranan humor superiority melalui kecerdasan emosi.

Hasil selanjutnya berdasarkan hasil pengolahan data diperoleh hasil bahwa ternyata ditemukan adanya peranan positif dan signifikan humor cognitive terhadap kecerdasan emosi. Dengan demikian hal ini menunjukkan bahwa apabila kecerdasan emosi tinggi maka humor cognitive menjadi tinggi, begitu juga sebaliknya apabila kecerdasan emosi rendah maka humor cognitive menjadi rendah.

Selanjutnya berdasarkan hasil pengolahan data diperoleh hasil bahwa ternyata ditemukan adanya peranan negatif dan signifikan kecerdasan emosi terhadap stres. Dengan demikian hal ini menunjukkan bahwa apabila kecerdasan emosi tinggi maka stres menjadi rendah, begitu juga sebaliknya apabila kecerdasan emosi rendah maka stres menjadi tinggi. Sedangkan untuk peranan humor cognitive terhadap stres tidak signifikan. Dengan demikian maka terbentuk mediasi pada peranan humor cognitive melalui kecerdasan emosi.

\section{Diskusi}

Berdasarkan hasil ditemukan kecerdasan emosi memediasi peranan humor superiority serta humor cognitive 
terhadap stres pada remaja. Dengan demikian dapat dilihat bahwa individu yang memiliki kecerdasan emosi tinggi lebih banyak tidak mengembangkan humor yang dengan tipe humor yang suka menyakiti pihak lain. Tipe humor ini jika dilihat dari konstruk butirnya maka dapat dilihat humor ini hanya melihat sesuatu yang lucu dengan stimulus kesulitan pada kehidupan pihak lain (pengelolaan humor terdapat sifat menjelekkan serta merendahkan pihak lain dalam hidup dengan menertawakannya). Dengan demikian pola hubungan yang terbentuk adalah ketika individu menggunakan humor superiority maka kecerdasan emosi yang diperoleh akan rendah sehingga menimbulkan stres yang tinggi. Sebaliknya jika seorang individu tidak menggunakan humor superiority misalnya dengan menggunakan humor cognitive maka kecerdasan emosi yang diperoleh akan tinggi sehingga menimbulkan stres yang rendah.

Hasil ini sejalan dengan Martin (2007) yang mengungkapkan bahwa menggunakan humor untuk menjatuhkan diri sendiri (self-defeating humor) cenderung memiliki perilaku stres yang tinggi. Demikian juga dengan Diener, Lucas, Oishi, dan Shu (2002) yang menemukan bahwa orang bahagia cenderung melihat pada pengalaman positif yang dialami dalam hidupnya, sementara orang yang tidak bahagia cenderung memfokuskan pada domain hidup yang paling menyulitkan. Selain itu juga temuan hasil penelitian tersebut juga diperkuat oleh penelitian yang dilakukan oleh Rumondor (2007) dan Nataatmaja (2012) dengan hasil yang sama bahwa humor yang bersifat affiliative memiliki korelasi negatif dengan stres dan humor yang bersifat self-defeating memiliki korelasi positif 
dengan stres. Dengan demikian dapat dilihat bahwa humor superiority akan mencerminkan orang yang merasakan perasaan negatif, sehingga penggunaan humor jenis ini sekaligus menunjukkan adanya dominasi perasaan tidak bahagia.

Penelitian ini memiliki beberapa keterbatasan diantaranya teknik sampling yang digunakan adalah convenience. Dengan demikian sampel di dalam penelitian ini merupakan sampel yang diambil dengan kemudahan sehingga tidak proporsional menggambarkan remaja yang ada di Jabodetabek. Selain itu dalam penelitian ini, tidak dikontrol variabel lain yang memiliki kemungkinan untuk diprediksi hubungannya variabel psikologi positif lain seperti quality of life, psychological well being (PWB). Dengan demikian penelitian ini perlu dilakukan penyempurnaan dengan meneliti hubungan dengan variabel psikologi positif lainnya.

\section{Saran Teoretis}

Secara teoretis penelitian ini memberikan manfaat bagi perkembangan ilmu psikologi terutama ilmu psikologi perkembangan remaja serta psikologi sosial. Dengan adanya penelitian ini maka secara teoretis bidang ilmu tersebut memeroleh manfaat dengan adanya fakta hasil penelitian sehingga secara empiris teoriteori menjadi ada buktinya. Penelitian ini memberikan pembuktian secara teoretis bahwa peranan humor superiority terhadap stres dapat dimediasi oleh kecerdasan emosi. Selain itu temuan dalam penelitian ini membuktikan bahwa humor superiority akan menimbulkan rendahnya kecerdasan emosi, oleh karena itu tidak disarankan untuk menggunakan jenis humor ini dengan tujuan meredakan 
stres pada kondisi sehari-hari melainkan menggunakan humor yang bersifat cognitive.

Saran secara teoretis terutama untuk penelitian selanjutnya diharapkan dapat meneliti peranan humor dengan variabel psikologi positif lain yang memungkinkan untuk diuji sebagai prediktif variabel berikutnya. Variabel lainnya tersebut misalnya quality of life, psychological well being (PWB).

\section{Saran Praktis}

Saran secara praktis peneliti berikan kepada para remaja dapat terus mengembangkan kecerdasan emosi serta komponen yang terkandung di dalamnya (meningkatkan perasaan positif dan melepaskan perasaan negatif) salah satunya dengan cara mengembangkan humor yang positif. Oleh karena itu, remaja senantiasa dapat mengembangkan kecerdasan emosi yang baik dengan mengurangi humor yang bersifat menyakiti pihak lain. Humor yang dikembangkan oleh individu yang memiliki kecerdasan emosi tinggi merupakan humor yang positif. Dengan demikian perasaan positif akan memberikan dampak kepada suasana hati yang baik dan akan memunculkan humor yang cerdas tanpa menyakiti pihak lain sehingga dapat memeroleh kebahagiaan sehingga dapat meredakan stres yang dialami dalam kehidupan sehari-hari.

\section{Daftar Pustaka}

Borchard, T. (2015, 22 November). Understanding humor can lead to new psychiatric treatments. Diunduh dari http://psychcentral.com/blog/archi ves/2014/02/07/understandinghumor can-lead-to-newpsychiatric-treatments/.

Christian, M. (2005). Jinakkan stres: Kiat hidup bebas tanpa tekanan. Bandung: Nexx Media.

Cann, A., Stilwell, K., \&Taku, K. (2010). Humor styles, positive personality, and health. Europe's 
Journal of Psychology, 6(3). 213235.

Diener, E., Lucas, R. E., Oishi, S., \& Suh, E. M. (2002). Looking up and down: Weighting good and bad information in life satisfaction judgements. Personality and Social Psychology Bulletin, 28, 437-445.

Davison, C. G., Neale, J. M., \& Kring, A. M. (2006). Abnormal psychology $\left(11^{\text {th }}\right.$ edition). NY: Jhon Willey and Sons, Inc.

Goleman, D. (2000). Kecerdasan emosional: Mengapa EI lebih penting daripada IQ? (T.Hermaya, Penerj.) Jakarta: Gramedia Pustaka Utama.

Hasanat, N.U. \& Subandi. (1998) Pengembangan alat kepekaan terhadap humor. Jurnal Psikologi. Tahun XXV No. 1, hlm 45-52.

Hartanti. (2002). Peran sense of humor dan dukungan sosial pada tingkat depresi penderita dewasa pascastroke. Anima, Indonesian PsychologicalJournal. 17, 2: 107119.

Lahey, B. B. (2007). Psychology an introduction (9th ed). Mc.Graw Hill: New York.

Martin, R. A. (2007). The psychology of humor: An integrative approach. Oxford: Elsevier.

Muawanah, L. B., Suroso., \& Pratikto, H. (2012). Kematangan emosi, konsep diri, dan kenakalan remaja. Jurnal Persona, 1(1), 6-14. Diunduh dari: http://jurnal.untag- sby.ac.id/index.php/persona/article /viewFile/9/25.

Nataatmaja, F. (2012). Hubungan antara humor styles dengan stres pada mahasiswa tahun pertama fakultas $y$ universitas $x$ di bandung. Skripsi. Bandung. Universitas Kristen Maranatha.

Papalia, D. E., Feldman, R. D., \& Martorell, G. (2012). Experience human development $\left(12^{\text {th }}\right.$ ed.). New York, NY: McGraw Hill.

Rumondor, P. C. B. (2007). Hubungan dimensi humor styles dengan stres pada mahasiswa tahun pertama. Skripsi. Universitas Indonesia. Depok.

Salovey, P., \& Mayer, J. D. (1997). What is emotional intelligence?. Diunduh dari http://ei.yale.edu/wpcontent/uploads/2014/02/pub219_ Mayer_Salovey_1997.pdf.

Utomo, U. H. N. (2009). Sense of humor: Studi psikometris tentang skala kepekaan terhadap humor versi a dan b. Laporan Penelitian. (tidak diterbitkan). Yogyakarta: Universitas Ahmad Dahlan.

Wijaya, E., \& Basaria, D. (2017) Hubungan humor dengan kecerdasan emosi pada remaja. Jurnal Provitae, 1(1). 13-25. 